\title{
The potential for digital and human workforce integration
}

\author{
Miriam Pekarčíková ${ }^{1}$, Peter Trebuňa ${ }^{1}$, Marek Kliment ${ }^{1}$, Michal Dic ${ }^{1}$ \\ 1 Technical University of Košice, Faculty of Mechanical Engineering, Institute of \\ Management, Industrial and Digital Engineering \\ Nemcovej 32, Košice, Slovakia \\ miriam.pekarcikova@tuke.sk \\ peter.trebuna@tuke.sk \\ marek.kliment@tuke.sk \\ michal.dic@tuke.sk
}

\begin{abstract}
Anotace: We are entering a new era of human-machine interaction and it is essential to underestimate the importance of people in the digital factory. Digital factories require a new way of working, this has several implications. The composition of the workforce wants to change, and companies want to be adequately employed and retain employees accordingly. It is equally important to work with people before and during the implementation of new technologies. The paper addresses the potential that the integration of digital and human labour can offer.
\end{abstract}

\section{Introduction}

Technological progress is rapidly pushing the boundaries between work tasks performed by humans and provided by machines and algorithms. If this transformation is conducted sensibly, it will lead not only to increased productivity, but also to an increase in the quality of life. Otherwise, it may pose a risk of widening skills gaps, inequality, and greater polarization. Research by the World Economic Forum in the report (for time frame 20182022) "Future of Jobs Survey 2018" suggests that by 2022, the introduction of technology into existing jobs can be expected to release workers and move them to jobs that will focus on for thinking and decision making.

The differences between work today and in the future, which are related to the introduction of new technologies and digitization, are shown in Figure 1. This is a change like the activities that will be provided to employees and that will be automated. The employee will no longer directly ensure the creation of added value, but the scope of his work will be focused on monitoring processes and robots, equipment maintenance, data evaluation and analysis processing, etc. The aim of the transformation should be to use new technologies to achieve a higher level of production and consumption efficiency, to expand into new product markets that reflect the needs of the global consumer base. 


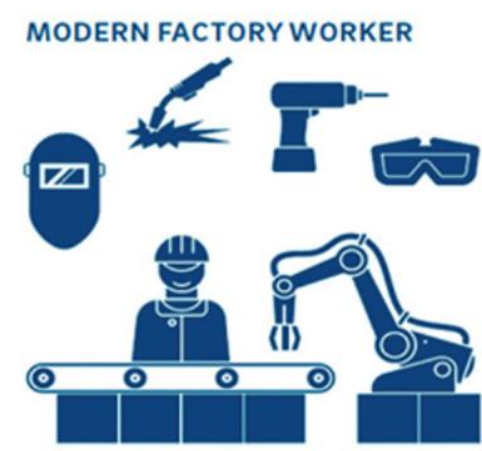

daily activities:

- direct added value

- work on machines

- work on one process at a time

required skills:

- manual skills,

- specialization in selected activities, e.g. welding, machining
DIGITAL FACTORY WORKER

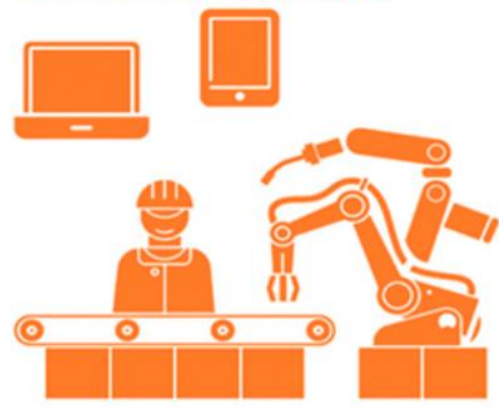

daily activities:

- indirectly added value

- monitoring of robots and processes

- simultaneous work on several processes

\section{required skills:}

- control of IT environment

- equipment maintenance

- statistical and analytical processes

Figure 1 - The differences between working today and in the future are influenced by Industry [1]

According to a source [2], Industry 4.0 will create new hybrid industries, such as digital medicine, precision agriculture and intelligent manufacturing. These will support the creation of new jobs, which may be similar, but will require excellent analytical skills and skills in the use of digital technologies. The machines will take over manual and routine work and people will be realized through their unique abilities and skills, such as creative problem solving, complex forms of communication, the ability to adapt to unknown situations.

Collaboration man vs. robot is another way to increase productivity, as it is the result of a combination of human flexibility and machine accuracy and consistency (for example, Amazon picking and completing orders). The Internet used in industry increases the flexibility of the system. By connecting to the network from anywhere, the worker can work asynchronously and remotely to solve problems related to machines, setting up machines independently, resp. in coordination with online collaborators.

The human factor in the context of Industry 4.0 will still be one of the most important factors. It will be part of an intelligent factory through creative and associative competencies. These are a person's natural abilities to use his intelligence, creativity, motor skills and empathy responsibly and sensibly in solving various situations. This will be crucial to the success of Industry 4.0. According to [2], the tasks and activities that the human factor should play in terms of Industry 4.0 can be categorized as follows:

1. Human sensory (sensory) abilities: even in the future, complex and ambiguous situations will arise in production processes, which will need to be solved by using the human factor.

2. Human ability to make decisions, and the associated way of thinking: to resolve conflicts between networked machines and devices, decision-making in critical situations. 
3. Human reactivity and ability to negotiate: complexity of the system, irregular repetition, flexibility, use of modern technologies, real-time reactions.

Monotonous activities will be automated and robotized, which will achieve higher productivity, efficiency and quality of production, improve the usability of working time, as the loss of time will no longer create downtime associated with the adjustment and adjustment of the machine, resp. with its maintenance. With increasing productivity, there is also an increase in wages and an increase in living standards. The source [2] states that currently 2 million robots are introduced in the industry, in the Slovak Republic it is mainly in the finalizing factories of automobiles. The mere addition of robots (not the exchange of people for robots) generates up to $0.4 \%$ of GDP per year worldwide. Thus, robotization does not mean an increase in unemployment, but a change like work, increased demands on qualifications, the acquisition of new knowledge and competencies with a focus on sophisticated activities.

According to prof. Mindella (a pioneer of autonomous robotics) the highest form of technology is not complete independence, but the automation and autonomy of the machine "elegantly" connected to the human operator.

Man will hold a prominent position in terms of his expertise and skills in production and customer needs with the potential to develop technologies that will respond to new future trends. The main goal of Industry 4.0 is to use the strengths of humans and robots and aim for the highest possible level of efficiency and productivity of production, Figure 2 .
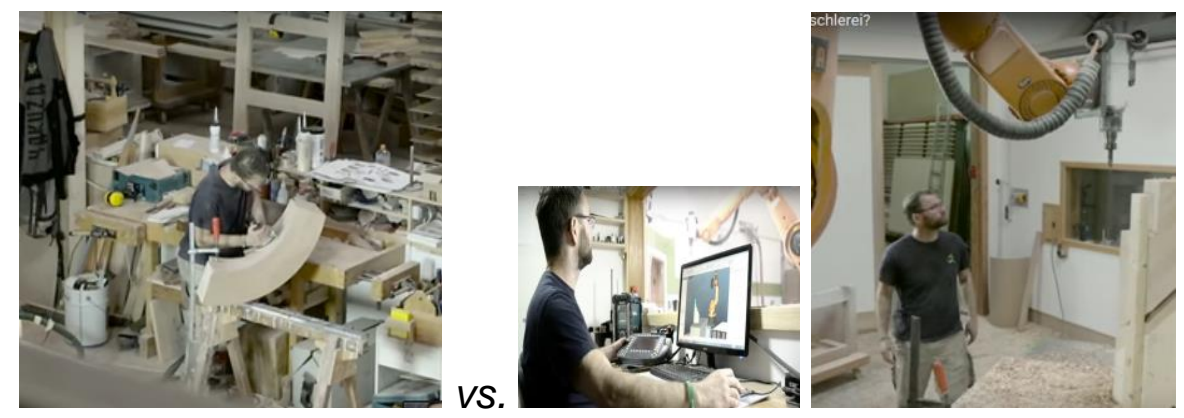

Figure 2 - The Human Factor in Industry [2]

The main driving force for the organization of work in the future will be the ability to think creatively and innovatively and implement designs through existing technologies. The main task of the company's management will be to motivate its employees. Robots will continue to receive instructions from humans. [2] The importance of the so-called emotional intelligence, which is a prerequisite for teamwork. Mutual interaction and motivation will be the main engine of business development. There is a need to change the hierarchy of human and business values, which should be based on a sense of security.

Industry 4.0 must be understood as a concept aimed at increasing competitiveness through collaboration and networking, promoting creativity 
and innovation, efficient use of resources, eliminating monotonous and physically demanding work, creating a cleaner and safer working environment, reconciling work and family life.

The report "Future of Jobs" (2016, World Economic Forum) points to the need to introduce a model of lifelong learning as one of the options for training professionals in the required field. Related to this, however, is the need to create a new educational infrastructure that will ensure a continuous change in professional and educational levels. In this context, two problems arise, namely the mental capacity of the population to undergo permanent processes in creative work and the problem of the population's adaptation to the transformation of complex systems. Due to geographical inequalities and the polarization of the global labour market and in conjunction with the growing power of information and communication technologies, the importance of teleworking will increase (flexible work). The aim will be to provide a skilled workforce with the skills that businesses need. Traditional models of permanent employment will be pushed out by "freelance workers" who will be able to fill this skills gap. $[3,4,5]$

Education will need to be dynamized and adapted to the constant development of digital technologies and to ensure that the knowledge and skills of the workforce are regularly updated in the form of platforms for the continuous learning process. Training and coaching will become the standard in the process of continuous improvement of business processes to achieve consistent results. Progress not only in technology means that the worker will have to have knowledge and competencies in various fields. For the company, the worker becomes an investment and not a cost. It is already necessary to reflect on these facts and set people up for the process of lifelong learning.

The impact of digital technologies on production and business processes will result in changes that will need to be faced by experimenting with new models and reforming the education and training system. Flexible education will have to copy the needs of the labour market. The classic way of education in the form of interpretation will have to be transformed into an interactive way aimed at supporting the development of creativity, analytical skills, and critical thinking.

"According to a McKinsey study (2017), automation should replace 400 to 800 million worldwide by 2030 jobs and up to $60 \%$ of professions must be more than $30 \%$ automated. According to analyses, up to $65 \%$ of children entering primary schools today end up in occupations that do not yet exist today. "[6]

To exploit the transformational potential of the Fourth Industrial Revolution, business leaders in all sectors and regions will be increasingly encouraged to develop a comprehensive workforce strategy ready to respond to the challenges of this new era of accelerating change and innovation. Key factors to consider include [7]: 
- mapping the extent of ongoing changes in employment and documenting emerging and declining types of jobs,

- highlighting opportunities to use new technologies to make human workers more efficient and to improve the quality of jobs,

- monitoring the development of skills required in connection with work,

- documenting the needs for investment in retraining, skills development and workforce transformation.

\section{Conclusion}

Many people claim that the human factor will no longer be needed in production in the future. Not only is this incorrect, but for economic reasons it does not make sense. The human factor will also play an important role in the Smart factory. The tasks that people perform in production today will change, the share of production activity will decrease, and the share of monitoring tasks will increase. Intelligent production means not only a high degree of automation, but also an increased need for workers who have expert knowledge in specific industries, as well as interdisciplinary skills and abilities to control new technologies and software in conjunction with the so-called soft skills that cannot be automated such as planning, coordination, leadership, cooperation, etc. The goal of building a functioning intelligent factory begins with the conviction of the workforce. Only then will the necessary change management be successfully implemented.

\section{Acknowledgement}

This article was created by the implementation of the grant project APVV-170258, APVV-19-0418, VEGA 1/0438/20 and KEGA 001TUKE-4/2020.

\section{Literature}

[1] Industry 4UM. Pre nastupujúcu transformáciu sú kvalifikovaní zamestnanci klúčoví, [online] 2018 [cit. 20. 7. 2020]. Available from:

https://industry4um.sk/pre-nastupujucu-transformaciu-su-kvalifikovanizamestnanci-klucovi

[2] BUREŠ, M. Metodika digitálního ergonomického návrhu a hodnocení pracovišt' ve strojírenských podnicích. Plzeň, 2010. Disertační práce. Západočeská univerzita. Fakulta strojní.

[3] VDMA. [online] 2019 [cit. 20. 7. 2020]. Available from: http://arbeitsmarkt.vdma.org/arbeit-4.0

[4] STANĚK, P., PAUHOFOVÁ, I. Pulzujúca ekonomika (Konceptuálne východiská k problematike). [online] 2016 [cit. 22. 7. 2020]. Available from: http://www.ekonom.sav.sk/uploads/journals/336 wp 86 stanek pauhofova 2016.pdf 
[5] Svet bez práce je ilúzia, vždy budú existovat' problémy, ktoré nezvládnu stroje., [online] 2017 [cit. 22. 7. 2020]. Available from:

https://openiazoch.zoznam.sk/cl/175300/Svet-bez-prace-je-iluzia-vzdy-buduexistovat-problemy-ktore-nezvladnu-stroje

[6] Report, Industrial Internet of Things. [online] 2018 [cit. 20. 7. 2020].

Available from: http://reports.weforum.org/industrial-internet-of-things/4-shifttowards-an-integrated-digital-and-human-workforce/4-2-creating-new-jobsin-hybrid-industries/9

[7] Digital factory. [online] Ceit, 2019 [cit. 22. 7. 2020]. Available from: http://ceitgroup.eu/index.php/sk/digital-factory-sk

[8] The Future of Jobs Employment, Skills and Workforce Strategy for the Fourth Industrial Revolution, Global Challenge Insight Report. [online] World Economic Forum, 2016 [cit. 20. 7. 2020]. Available from: http://www3.weforum.org/docs/WEF Future of Jobs.pdf

[9] GREGOR, M., HERCKO, J., GRZNAR, P. The Factory of the Future Production System Research. 21st International Conference on Automation and Computing (ICAC), 2015, 254-259. doi: 10.1109/IConAC.2015.7313998.

[10] KOBLASA, F., ŠíROVÁ E., KRÁLIKOVÁ, R. The Use of Process Thinking in The Industrial Practice - Preliminary Survey. The Journal Tehnički vjesnik Technical Gazette, 2019, 26(3). doi: 10.17559/TV-20150617135306. ISSN 1848-6339.

[11] STRAKA, M., SADEROVA, J., BINDZAR, P., MALKUS, T., LIS, M. Computer simulation as a means of efficiency of transport processes of raw materials in relation to a cargo rail terminal: A case study. Acta Montanistica Slovaca, 2019, 24(4), 307-317.

[12] WICHER, P., STAS, D., KARKULA, M., LENORT, R., BESTA, P. A Computer Simulation-Based Analysis Of Supply Chains Resilience. Industrial Environment: Metalurgija, 2015, 54(4), 703-706.

[13] ROSOVA, A. Methods and approaches to the evaluation of company performance. Poprad Economic And Management Forum, 2017, 31-36. ISBN 978-80-561-0519-1.

[14] GLOVA, J., SABOL, T., VAJDA, V. Business Models for the Internet of Things Environment: Emerging Markets Queries. Finance And Business, Procedia Economics and Finance, 2014, 15, 1122-1129. doi: 10.1016/S2212-5671(14)00566-8. 